\title{
Human Capital Disclosure in the MD\&A Statement: An Analysis on Italian Public Utilities
}

\author{
Sabrina Pisano \\ Department of Law, University of Naples "Parthenope", Naples, Italy
}

Email address:

sabrina.pisano@uniparthenope.it

To cite this article:

Sabrina Pisano. Human Capital Disclosure in the MD\&A Statement: An Analysis on Italian Public Utilities. Journal of Human Resource Management. Special Issue: Challenges and Opportunities in the Performance Measurement and Control Systems of Human Resources Management for the Services Industry. Vol. 3, No. 2-1, 2015, pp. 39-46. doi: 10.11648/j.jhrm.s.2015030201.16

\begin{abstract}
Over the last years, the relevance of human capital disclosure has been widely recognized by academics, regulators and professional standards setters. In 2003, the EU issued Directive 2003/51/EC, which required companies to provide in their management discussion and analysis statement information relating to human capital. In Italy, the Accounts Modernisation Directive was implemented through Legislative Decree 32/2007, which became effective for reports for the financial years beginning on or after April 12 $2^{\text {th }}, 2007$. In March 2009, the Italian professional standards setter issued a more explicit guidance on the type of human capital information a firm could discuss in its management discussion and analysis. This study examines the disclosure on human capital provided by a sample of Italian listed public utilities in their management discussion and analysis in 2008 and 2009. The aim of the study is to determine the amount and the content of human capital disclosure released by Italian listed public utilities after the issuing of the new rule. This is an explorative study conducted through a qualitative approach and the use of multiple case study methodology. The sample is composed of 7 Italian public utilities selected using a random procedure. To collect data on human capital disclosure it has been used content analysis, that is the research method most utilized in intellectual capital disclosure studies. The items of human capital information have been identified using the new legal requirements and the guidance issued by the Italian professional standards setter. The results are consistent with prior studies on intellectual capital disclosure showing that the amount of human capital information provided is very small. However, the findings show a slight improvement in the amount of human capital disclosures released during the years. With respect to the content, companies mainly released information on the number of employees, the investments in human capital and the description of the program of training. This paper contributes to the intellectual capital literature in two ways: first, it shows the human capital disclosure practices of Italian public utilities after the issuing of a new rule, rather than analyze the information voluntarily provided, and compares these findings with previous studies; moreover, it identifies the items of human capital information on the basis of the new requirements, rather than use the models developed in the intellectual capital literature, suggesting a framework that could be used in future researches conducted on companies listed in other European Union member states.
\end{abstract}

Keywords: Human Capital Disclosure, MD\&A Statement, Italian Public Utilities

\section{Introduction}

In the last years, the traditional financial statement has been considered inadequate in meeting the information needs of users $[1,2,3]$ mainly because, for their structure and content, the balance sheet and the income statement are not able to provide adequate information about corporate intangible assets [4] and, in particular, about intellectual capital. In fact, the traditional financial reporting model fails in recognizing most value creation drivers, such as human capital, inter-firm relationships, customer relationships $[2,5]$, that are considered useful by stakeholders and, among these, by investors when they have to decide in which company invest their money.

In this context, researchers, regulators and professional standards setters suggested companies to voluntarily provide information on intellectual capital in their annual report, in order to permit a better understanding of the value creation 
drivers not represented in the financial statement. More specifically, the professional standards setters of different countries issued several guidance illustrating examples of the intellectual capital disclosure a company should release $[6,7$, $8,9,10]$. Researchers, instead, developed different intellectual capital models and measures [11, 12, 13], and conducted several analysis on the amount of intellectual capital disclosure voluntarily provided in the annual report by companies operating in different countries.

From the regulator's perspective, in 2003 the EU issued Directive 2003/51/EC, which required companies to provide in their management discussion and analysis (MD\&A) statement information relating to the human capital, which is a component of the intellectual capital.

In Italy, the Accounts Modernisation Directive was implemented through Legislative Decree 32/2007, which became effective for reports for the financial years beginning on or after April 12 $2^{\text {th }}, 2007$. In March 2009, the Italian professional standards setter issued a more explicit guidance on the type of human capital information a firm could discuss in its MD\&A.

This study examines the disclosure on human capital provided by a sample of Italian listed public utilities in their MD\&A statement in the years 2008 and 2009. The aim of the study is to determine the amount and the content of human capital disclosure provided by Italian listed public utilities after the issuing of Legislative Decree 32/2007. The decision to investigate the utilities derives from the consideration that, for their activity, these companies are more exposed to the interest of several stakeholders; as a consequence, it is likely that they pay much attention to the human capital disclosure. Moreover, the choice to analyze the years 2008 and 2009 derives from the consideration that in 2008 companies had to draw up their MD\&A according to the new rule for the first time. In 2009, instead, the Italian professional standards setter issued its guidance; so it is possible that companies increased the human capital information provided because they could make reference to the examples contained in the guidance.

This paper differs from previous studies on intellectual capital disclosure for several reasons. First, because it analyzes a specific intellectual capital component, i.e. the human capital. Moreover, it investigates the disclosure provided after the issuing of a new rule and defines the items of human capital to disclose on the basis of the Accounts Modernisation Directive 2003/51/EC, the Legislative Decree $32 / 2007$ and the guidance issued by the Italian professional standards setter, rather than use the models developed by the intellectual capital literature. Finally, the paper examines the information disclosed in a specific document, the MD\&A, rather than analyze the whole annual report.

The results are consistent with prior studies on intellectual capital disclosure showing that the amount of human capital information provided is very small. However, the findings show a slight improvement in the amount of human capital disclosures released during the years. With respect to the content, companies mainly released information on the number of employees, the investments in human capital and the description of the program of training.

The paper is structured as follows: section 2 provides an overview of previous studies on human capital disclosure, section 3 describes the new MD\&A requirements according to Accounts Modernisation Directive 2003/51/EC, Legislative Decree 32/2007 and the guidance issued by the Italian professional standards setter. In section 4, the sample and research method are described. Section 5 illustrates and discusses the results emerging from the analysis. Finally, Section 6 draws some conclusions, limitations and suggestions for future research.

\section{The Human Capital Disclosure}

The intellectual capital models developed by researchers $[11,12,13]$ identify three intellectual capital components: human capital, structural capital and relational capital [12, 13].

This paper focuses on the first component, i.e. the human capital. So, this section reviews previous studies on intellectual capital disclosure focusing exclusively on the results concerning the human capital component.

Several studies have been developed aiming at analyze the amount of voluntary intellectual capital disclosure provided by firms in Australia [14, 15], Ireland [16], UK [17, 18], Italy [18, 19], Denmark [20], Spain [21], Portugal [22], Singapore [23] and New Zealand [24]. The main document that has been analyzed is the annual report, but there are also studies focusing on the reports of presentations to financial analysts [21] or the IPO prospectuses [20, 23] (see table 1). All these studies used a framework developed by the intellectual capital literature to analyze the amount of disclosure provided by companies.

With specific regard to human capital disclosure, we identified the following conclusions from previous studies. First, researchers found that the human capital is the least frequently reported intellectual capital category. By the way of example, Bukh et al. [20] found that only 17,8 per cent of companies provided information on human capital; Bozzolan et al. [19] found that 6 out of 30 firms investigated did not disclose human capital information. Similar results were found also by Brennan [16] and White et al. [15].

When disclosed, the amount of human capital information released is very small. Bozzolan et al. [19], for example, found that only 21 per cent of the intellectual capital information disclosed concerned human capital and the average number of human capital elements provided was 11. The Authors explained this small value of human capital disclosure by the argument that, «although managers would like to offer additional relevant or useful information to the public, they are concerned about the risk of such information being used by competitors». Similar results were found also by Oliveira et al. [22].

Another conclusion from previous studies is that the human capital information reported by companies is generally presented in a qualitative form $[16,21,22]$. 
Table 1. Previous studies on intellectual capital disclosure

\begin{tabular}{|c|c|c|c|c|}
\hline Study & Country & Document analyzed & Sample & $\begin{array}{l}\text { Framework for identifying intellectual } \\
\text { capital items }\end{array}$ \\
\hline $\begin{array}{l}\text { Guthrie and Petty } \\
(2000)\end{array}$ & Australia & Annual reports & 20 listed companies & 24 items from Sveiby (1997) \\
\hline Brennan (2001) & Ireland & Annual reports & 11 listed companies & 24 items from Guthrie and Petty (2000) \\
\hline Williams (2001) & UK & Annual reports & $\begin{array}{l}31 \text { companies from FTSG } 100 \\
\text { index }\end{array}$ & 50 items from intellectual capital literature \\
\hline Bozzolan et al. (2003) & Italy & Annual reports & $\begin{array}{l}30 \text { non-financial listed } \\
\text { companies }\end{array}$ & 22 items from Guthrie and Petty (2000) \\
\hline Bozzolan et al. (2006) & Italy UK & Annual reports & 60 listed companies & 22 items from Guthrie and Petty (2000) \\
\hline Bukh et al. (2005) & Denmark & IPO prospectuses & 68 IPO prospectuses & 78 items from intellectual capital literature \\
\hline $\begin{array}{l}\text { García-Meca and } \\
\text { Martínez (2005) }\end{array}$ & Spain & $\begin{array}{l}\text { Reports of presentations } \\
\text { to analysts }\end{array}$ & 257 reports & 71 items from intellectual capital literature \\
\hline Oliveira et al. (2006) & Portugal & Annual reports & 56 listed companies & 32 items from intellectual capital literature \\
\hline White et al. (2007) & Australia & Annual reports & 96 listed companies & 78 items from Bukh et al. (2005) \\
\hline $\begin{array}{l}\text { Singh and Van der } \\
\text { Zahn (2008) }\end{array}$ & Singapore & IPO prospectuses & 444 IPO prospectuses & 89 items from intellectual capital literature \\
\hline $\begin{array}{l}\text { Whiting and Miller } \\
(2008)\end{array}$ & New Zealand & Annual reports & 70 listed companies & 18 items from Guthrie et al. (2004) \\
\hline
\end{tabular}

Finally, some scholars found a slight improvement in the amount of human capital information disclosed during the years. By the way of example, Bukh et al. [20] showed that the average number of human capital items disclosed increased from 1990 to 2001. Similar results were found by both Williams [17] for the period 1996-2000 and Singh and Van der Zahn [23] for the period 1997-2006.

On the basis of previous studies, the aim of this paper is to determine both the amount and the content of human capital disclosure provided by Italian listed public utilities after the issuing of the new rule. As a consequence, in developing our disclosure index we decided to refer to the content of the Accounts Modernisation Directive 2003/51/EC, the Legislative Decree 32/2007 and the guidance issued by the Italian professional standards setter, rather than use a framework developed in the intellectual capital literature.

\section{The New MD\&A Requirements on Human Capital Disclosure}

Italian law requires firms to prepare a MD\&A statement as part of their annual report (art. 2428 of the Civil Code).

In Italy, the MD\&A statement is a mandatory narrative document, whose function is to complement the information contained in the financial statement by providing an analysis of the development and performance of the company's business and its position (art. 2428, paragraph 1). In addition to this general requirement, Italian law requires firms to provide a description of some specific topics, such as their costs, revenues and capital expenditures, research and development activities, interfirm relationships, the ownership or purchase/sale of their shares, the secondary registered office, corporate governance structure, financial instruments, the most important events occurring between the end of the year and the annual report's publication date and the possible evolution of the business (art. 2428, paragraph 3).
Considering the legal requirements, it is possible to affirm that, although the Italian MD\&A is a mandatory document, its content is both mandatory and voluntary. In fact, except for the specific topics compulsorily required by paragraph 3 of art. 2428 , firms are free to decide both the information to provide in their MD\&A and the format for its presentation.

For this characteristic, some scholars define the MD\&A statement as both an open document [25] and the natural place for voluntary disclosures [26].

In 2007, the Italian legislator implemented in Italy the compulsory section of the Accounts Modernisation Directive 2003/51/EC, issuing Legislative Decree 32/2007, which both broadened the content of the first paragraph and introduced a second paragraph to art. 2428 , requiring firms to provide more information in their MD\&A.

The new paragraphs of art. 2428 state that:

"1. A firm has to prepare a Management Discussion and Analysis, that shall include at least a fair, balanced and comprehensive analysis of the development and performance of the company's business and of its position, with specific regard to costs, revenues and capital expenditures, together with a description of the principal risks and uncertainties that it faces.

2. This review shall be consistent with the size and complexity of the business and, to the extent necessary for an understanding of the company's development, performance or position, the analysis shall include both financial and, where appropriate, non-financial key performance indicators relevant to the particular business, including information relating to environmental and employee matters. In providing its analysis, the Management Discussion and Analysis shall, where appropriate, include references to and additional explanations of amounts reported in the financial statement." 
(Art. 2428 of the Civil Code, paragraphs 1 and 2)

Considering the aim of this paper, it is important to note the new requirement of paragraph 2 , stating that the analysis shall include information relating to employee matters. In other words, companies are required to provide human capital information in their MD\&A.

The aim of the Italian legislator, in fact, has been to broaden the Italian MD\&A disclosures, in order to provide financial statement users relevant information for better understanding and evaluating the company and, among this, human capital information.

Although the new requirement to discuss human capital information in the MD\&A statement, the format for its presentation and the items to disclose continue to be deliberately not specified however.

This means that Italian companies can voluntarily decide both the human capital information to disclose and how to provide this information. As a consequence, it is possible to find great variety across firms and industries in the information provided in their MD\&A.

To help firms in preparing their MD\&A, in 2009 the Italian professional standards setter issued some more explicit guidance on the type of information a firm could discuss in its MD\&A under the new legal requirements. With specific regard to human capital disclosure, in March 2009 the Italian professional standards setter issued the document " $L a$ relazione sulla gestione art. 2428 codice civile. Informativa sull'ambiente e sul personale" [27], that provides a list of information that firms could discuss in their MD\&A statement and contains some examples of information relating to human capital disclosure.

\section{Sample and Research Method}

This section explains the methodological approach used in the study. More specifically, subsection 4.1. describes how the sample was drawn and the data were collected. Subsection 4.2. instead, focuses on the technique used for the analysis of the content of MD\&A statements.

\subsection{Sample Selection and Data Collection}

This study focuses on a sample of 7 companies chosen from the public utilities listed in both 2008 and 2009 on the Italian stock exchange.

Similar to previous researches [14-19], this paper investigates the disclosure on human capital provided by a sample of companies. To define the sample, we first identified the sector to analyze and then selected the firms using a simple random procedure.

With respect to the sector, we decided to investigate the public utilities because, for their activity, these companies are more exposed to the interest of several stakeholders; as a consequence, it is likely that they pay much attention to the human capital disclosure.

As stated in the introduction, we analyzed the disclosure provided in the years 2008 and 2009. These years have been chosen because firms have the latest MD\&A requirements under Italian law in 2008 and the latest guidance from the Italian professional standards setter in 2009.

The complete list of public utilities listed in both 2008 and 2009 on the Italian stock exchange consisted of 21 firms. Considering that this is an exploratory study, we decided to investigate one third of the utilities, so 7 firms.

Table 2 shows the list of the companies included in the sample. The table also reports the value of the sales in both 2008 and 2009 for each firm, as a proxy of their size.

Table 2. The sample

\begin{tabular}{ll|l}
\hline Company & Sales 2008 (€/000) & Sales 2009 (€/000) \\
\hline Acegas-Aps & 437.036 & 436.841 \\
Ascopiave & 824.672 & 764.151 \\
Edison & 10.064 .000 & 8.867 .000 \\
Hera & 3.716 .336 & 4.204 .204 \\
Iride & 1.589 .063 & 1.274 .590 \\
Saipem & 10.292 .000 & 10.094 .000 \\
Snam Rete Gas & 2.438 .000 & 1.902 .000 \\
\hline
\end{tabular}

Most of the sampled companies are multi-utilities, so they provide several services (i.e. water, gas, energy). Only two firms provide just one service: Saipem provides energy service and Snam Rete Gas provides gas service.

The companies analyzed differ each other in terms of size. In 2008, in fact, the minimum value of the sales was $€$ 437.036.000 (Acegas-Aps) and the maximum was $€$ 10.292.000.000 (Saipem). In the same vein, in 2009 the minimum value of the sales was $€ 436.841 .000$ (Acegas-Aps) and the maximum was $€ 10.094 .000 .000$ (Saipem).

The sources of data were the MD\&A statements drawn up for both 2008 and 2009. We gathered these documents from the web-site of each listed company and content analyzed them using the research method described in the next subsection.

\subsection{Research Method}

To collect data on human capital disclosure we used content analysis [28], that is the research method most used in intellectual capital disclosure studies [29].

The coding procedure was organized as follows. Firstly, we identified the items of human capital information that a firm should discuss in its MD\&A using the new legal requirements and the guidance issued by the Italian professional standards 
setter. In particular, we identified 11 human capital disclosure items that a firm should provide in its MD\&A.

Table 3 provides the list of human capital disclosure items identified.

Table 3. The human capital disclosure items

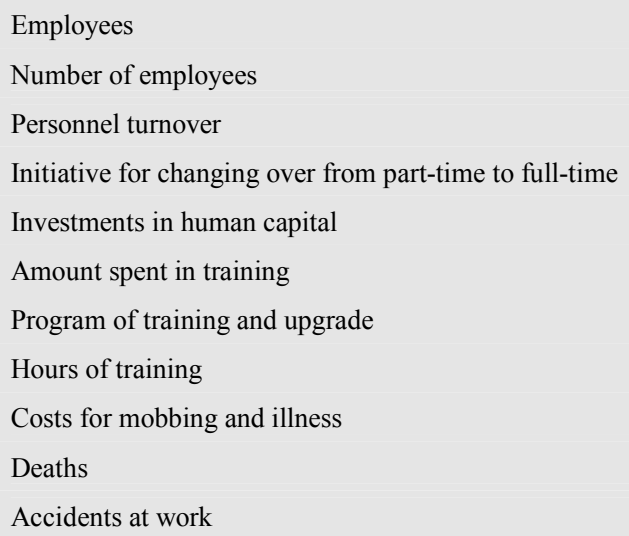

Once the human capital disclosure items were identified, the MD\&A statements issued in 2009 and 2010 (for fiscal years 2008 and 2009) were analyzed for each public utility, and data were collected for each item of information.

The analysis was conducted by two assistant researchers. The sentences (defined as a set of words that is complete in itself) have been chosen as the recording units. The decision to focus on the sentences derived from the consideration that the Italian legislator did not specify the information to disclose. So, Italian public utilities could voluntarily decide the human capital items of information to disclose. As a consequence, the analysis of the sentences could permit a better understanding of the disclosure behavior adopted by each Italian public utility.

Each sentence was coded according to its content, by using the computer software package QSR NVivo $8^{1}$. This software is a computer package designed to assist researchers in the analysis of narrative documents, by supporting the processes of coding data.

To align the set of coding rules, a preliminary test was conducted among coders. In particular, two MD\&As were coded independently, in order to identify the differences between coders. Then, these differences were discussed and, on the basis of this discussion, the final set of coding rules was defined.

Once the MD\&A statements of each public utility were read, a score was assigned to each firm, equal to the amount of sentences disclosed for the human capital items of information identified. In this way, the amount of human capital disclosures provided by each public utility was computed.

\section{Results}

Table 4 shows the human capital disclosures provided in the

1 The use of this software was introduced to the academic journal literature by Beattie et al. [30].
MD\&A statement by the sampled companies for 2008 and 2009.

The percentage of firms providing information for each item identified shows the completeness of the Italian public utilities' MD\&A statements with respect to human capital disclosure. As table 4 shows, all the sampled companies provided information exclusively concerning the following items: Employees and Number of employees for both 2008 and 2009. This result is in line with previous studies on intellectual capital disclosure showing that the human capital is the least frequently reported category $[15,16,19,20]$. However, the results reveal an increase in the percentage of firms providing information for almost all the items concerning the information on training (Investments in human capital, Program of training and upgrade and Amount spent in training) from 2008 to 2009. On the other hand, there are no firms providing information on Personnel turnover, Initiative for changing over from part-time to full-time, Costs for mobbing and illness and Deaths (see also table 6). With regard to the last two items, this result could be due to two different reasons: on one hand, it could be that the company did not present these specific situations and so did not provide information on them; on the other hand, it could be that the firm voluntarily decided to not provide information on mobbing or death because this kind of disclosure could damage its image. Finally, just one company (Edison) provided information on the Accidents at work (table 6).

With respect to the information released for each item, the third and fourth columns of table 4 show both how much information firms provided in their MD\&A for each item on average (Mean of sentences) and how the disclosure behavior differed among firms (Standard deviation of sentences) for 2008 and 2009. Finally, the last two columns illustrate the total amount of sentences (in absolute value and in percentage) disclosed by all the sampled companies for each item for both 2008 and 2009.

In line with previous studies $[19,22]$, the findings reveal that the amount of human capital information provided is very small: on average the sampled companies disclosed 22.43 sentences in 2008 and 35.86 in 2009. Moreover, the standard deviation shows relatively high values for both the years (11.19 in 2008 and 25.77 in 2009), revealing that the disclosure behaviors adopted by Italian public utilities have not been homogeneous.

The item with the highest percentage of sentences is Program of training and upgrade in 2008 and Investments in human capital in 2009. So the sampled companies paid much attention to the description of the program of training, but they did not provide too much information on the training costs and hours. Moreover, table 4 shows that also the item Number of employees presents high percentage of sentences, but this result is not unexpected, considering that art. 2427 of the civil code requires companies to release information on the number of employees in the note of the financial statement. So, the sampled firms repeated the information contained in the note in their MD\&A statement. 
Table 4. The Italian public utilities human capital disclosure

\begin{tabular}{|c|c|c|c|c|c|c|c|c|c|c|}
\hline \multirow{2}{*}{ Human capital item } & \multicolumn{2}{|c|}{$\%$ of firms } & \multicolumn{2}{|c|}{ Mean of sentences } & \multicolumn{2}{|c|}{ Std. d. of sentences } & \multicolumn{2}{|c|}{ N. of sentences } & \multicolumn{2}{|c|}{$\%$ of sentences } \\
\hline & 2008 & 2009 & 2008 & 2009 & 2008 & 2009 & 2008 & 2009 & 2008 & 2009 \\
\hline Employees & $100.00 \%$ & $100.00 \%$ & 2.86 & 7.29 & 2.91 & 6.85 & 20 & 51 & $12.74 \%$ & $20.32 \%$ \\
\hline Number of employees & $100.00 \%$ & $100.00 \%$ & 5.29 & 7.00 & 4.07 & 4.58 & 37 & 49 & $23.57 \%$ & $19.52 \%$ \\
\hline Personnel turnover & $0.00 \%$ & $0.00 \%$ & 0.00 & 0.00 & 0.00 & 0.00 & 0 & 0 & $0.00 \%$ & $0.00 \%$ \\
\hline $\begin{array}{l}\text { Initiative for changing over from } \\
\text { part-time to full-time }\end{array}$ & $0.00 \%$ & $0.00 \%$ & 0.00 & 0.00 & 0.00 & 0.00 & 0 & 0 & $0.00 \%$ & $0.00 \%$ \\
\hline Amount spent in training & $14.29 \%$ & $28.57 \%$ & 0.29 & 0.43 & 0.76 & 0.79 & 2 & 3 & $1.27 \%$ & $1.20 \%$ \\
\hline Program of training and upgrade & $85.71 \%$ & $100.00 \%$ & 10.43 & 7.29 & 8.64 & 7.97 & 73 & 51 & $46.50 \%$ & $20.32 \%$ \\
\hline Hours of training & $57.14 \%$ & $57.14 \%$ & 1.43 & 1.14 & 1.81 & 1.21 & 10 & 8 & $6.37 \%$ & $3.19 \%$ \\
\hline Costs for mobbing and illness & $0.00 \%$ & $0.00 \%$ & 0.00 & 0.00 & 0.00 & 0.00 & 0 & 0 & $0.00 \%$ & $0.00 \%$ \\
\hline Deaths & $0.00 \%$ & $0.00 \%$ & 0.00 & 0.00 & 0.00 & 0.00 & 0 & 0 & $0.00 \%$ & $0.00 \%$ \\
\hline Accidents at work & $14.29 \%$ & $14.29 \%$ & 0.71 & 1.00 & 1.89 & 2.65 & 5 & 7 & $3.18 \%$ & $2.79 \%$ \\
\hline Total & & & 22.43 & 35.86 & 11.19 & 25.77 & 157 & 251 & $100.00 \%$ & $100.00 \%$ \\
\hline
\end{tabular}

Finally, the results show an increase both in the number of sentences disclosed from 2008 (157) to 2009 (251), and in the mean of sentences disclosed by all the sampled companies from 2008 (22.43) to 2009 (35.86). This finding is consistent with prior studies showing a slight improvement in the amount of human capital information disclosed during the years [17, 20,23]. There are two possible explanations for this result: on one hand, it could be that Italian public utilities recognized the importance of the new MD\&A requirements on human capital, increasing the amount of information provided; on the other hand, it could be that firms increased the information disclosed because they made reference to the examples of human capital disclosure contained in the guidance issued in 2009 by the Italian professional standards setter.

Table 5 reports the number of human capital sentences disclosed by each company in 2008 and 2009.

Table 5. The number of human capital sentences disclosed by each firm

\begin{tabular}{ll|l}
\hline Company & Human capital disclosure in 2008 & Human capital disclosure in 2009 \\
\hline Acegas-Aps & 15 & 15 \\
Ascopiave & 4 & 7 \\
Edison & 35 & 27 \\
Hera & 30 & 64 \\
Iride & 15 & 31 \\
Saipem & 29 & 78 \\
Snam Rete Gas & 29 & 29 \\
\hline
\end{tabular}

The company that provided the highest number of human capital sentences was Edison in 2008 and Saipem in 2009, while the firm that disclosed the lowest number of human capital sentences was Ascopiave in both 2008 and 2009. Considering the size of these companies reported in table 2, it seems that there is no relation between size and human capital disclosure, although previous studies suggested that size is an important determinant of intellectual capital disclosure $[15,18,19,21,22]$. However, this assumption needs to be empirically verified with further analysis.

With respect to the increase in the number of sentences disclosed, the results show that, except for Acegas-Aps, Edison and Snam Rete Gas, the other sampled companies enhance the number of human capital sentences from 2008 to 2009. As previous stated, this result could be explained both by the increased relevance recognized to the new MD\&A requirements on human capital by the Italian public utilities and by the issuing of the guidance by the Italian professional standards setter.
With respect to the companies that did not increase the number of sentences from 2008 to 2009 , it is necessary to distinguish Edison from Acegas-Aps and Snam Rete Gas. The last two firms, in fact, did not modify both the number of sentences provided and the items of human capital information disclosed. In other words, these firms did not vary both the amount and the content of human capital disclosure from 2008 to 2009 , as shown in table 6 . There are two possible explanations for these results: on one hand, it could be that both these companies presented the same situation in 2008 and 2009 and, as a consequence, did not vary the information disclosed; on the other hand, it could be that they voluntarily decided to not release information on other human capital items because they thought that this kind of data could damage their image. Differently from Acegas-Aps and Snam Rete Gas, Edison decreased the number of sentences disclosed. More specifically, the company reduced the amount of information provided for the following items: Number of employees, Investments in human capital, Program of training and 
upgrade. With respect to the item Number of employees, it could be that Edison decided to reduce this kind of information in the MD\&A statement because it is also reported in the note of the financial statement, as required by art. 2427 of the civil code. With regard to the items
Investments in human capital and Program of training and upgrade, instead, it could be that the company did not present these situations in 2009 and, as a consequence, did not report data on them in its MD\&A statement.

Table 6. The Italian public utilities human capital disclosure provided by each firm

\begin{tabular}{|c|c|c|c|c|c|c|c|c|c|c|c|c|c|c|}
\hline \multirow[t]{2}{*}{ Human capital item } & \multicolumn{2}{|c|}{ Acegas-Aps } & \multicolumn{2}{|c|}{ Ascopiave } & \multicolumn{2}{|c|}{ Edison } & \multicolumn{2}{|l|}{ Hera } & \multicolumn{2}{|l|}{ Iride } & \multicolumn{2}{|c|}{ Saipem } & \multicolumn{2}{|c|}{$\begin{array}{l}\text { Snam Rete } \\
\text { Gas }\end{array}$} \\
\hline & 2008 & 2009 & 2008 & 2009 & 2008 & 2009 & 2008 & 2009 & 2008 & 2009 & 2008 & 2009 & 2008 & 2009 \\
\hline Employees & 2 & 2 & 0 & 2 & 1 & 5 & 2 & 11 & 1 & 3 & 7 & 21 & 7 & 7 \\
\hline Number of employees & 6 & 6 & 4 & 3 & 12 & 7 & 4 & 10 & 9 & 15 & 1 & 7 & 1 & 1 \\
\hline Personnel turnover & 0 & 0 & 0 & 0 & 0 & 0 & 0 & 0 & 0 & 0 & 0 & 0 & 0 & 0 \\
\hline $\begin{array}{l}\text { Initiative for changing over from } \\
\text { part-time to full-time }\end{array}$ & 0 & 0 & 0 & 0 & 0 & 0 & 0 & 0 & 0 & 0 & 0 & 0 & 0 & 0 \\
\hline Investments in human capital & 0 & 0 & 0 & 1 & 4 & 1 & 4 & 23 & 2 & 10 & 0 & 47 & 0 & 0 \\
\hline Amount spent in training & 0 & 0 & 0 & 0 & 0 & 2 & 2 & 1 & 0 & 0 & 0 & 0 & 0 & 0 \\
\hline Program of training and upgrade & 6 & 6 & 0 & 1 & 11 & 3 & 13 & 16 & 1 & 1 & 21 & 3 & 21 & 21 \\
\hline Hours of training & 1 & 1 & 0 & 0 & 2 & 2 & 5 & 3 & 2 & 2 & 0 & 0 & 0 & 0 \\
\hline Costs for mobbing and illness & 0 & 0 & 0 & 0 & 0 & 0 & 0 & 0 & 0 & 0 & 0 & 0 & 0 & 0 \\
\hline Deaths & 0 & 0 & 0 & 0 & 0 & 0 & 0 & 0 & 0 & 0 & 0 & 0 & 0 & 0 \\
\hline Accidents at work & 0 & 0 & 0 & 0 & 5 & 7 & 0 & 0 & 0 & 0 & 0 & 0 & 0 & 0 \\
\hline Total & 15 & 15 & 4 & 7 & 35 & 27 & 30 & 64 & 15 & 31 & 29 & 78 & 29 & 29 \\
\hline
\end{tabular}

\section{Concluding Remarks}

This paper has analyzed the human capital disclosure provided by a sample of Italian public utilities for the years 2008 and 2009. Using the content analysis, the paper has examined the amount and the content of disclosure provided in the MD\&A statement after the implementation of Legislative Decree 32/2007.

The findings showed that the amount of human capital information provided by the sample of Italian listed public utilities is very small both in 2008 and in 2009 . However, the findings revealed a slight improvement in the amount of human capital disclosures during the years. This could be the consequence of an increasing interest to human capital disclosure by companies or of the issuing of the guidance by the Italian professional standards setter, that gave examples of human capital disclosure to firms. With respect to the content, the results showed that companies mainly released information on the number of employees, the investments in human capital and the description of the program of training.

This research should be of interest to both academics and regulators. From the academic perspective, the research adds to the intellectual capital literature by examining the human capital disclosure released by a sample of Italian listed public utilities after the issuing of a new rule, rather than analyze the information voluntarily provided. Moreover, this study suggests a framework to investigate the human capital disclosure based on the new MD\&A requirements, that could be used for future research on the disclosure behavior of companies operating in other European Union member states. This could permit the identification of benchmarks of human capital disclosure.

From the regulator's perspective, the findings of this research could be useful to both the European and the Italian legislator by providing insights on the items of human capital information that are less disclosed by Italian companies and, consequently, on the items of human capital information that should require some improvements.

The study is exploratory in nature and presents some limitation. So, further work needs to be done in several ways. First, the sample includes only 7 public utilities listed on the Italian stock market, hence the results may not be generalized to all Italian companies. As a consequence, future research could use a larger sample and extend the analysis to companies belonging to other sectors. Moreover, it could be interesting to investigate the determinants of the companies' disclosure behavior developing a regression model. In addition, the study investigates only two years, but it could be interesting to further extend the analysis in order to better understand the development of human capital disclosure. Finally, it could be interesting to analyze the attributes of disclosure, such as the time orientation (forward-looking or present or past), the nature (qualitative or quantitative) and the type (financial or non-financial) of the human capital information disclosed.

\section{References}

[1] J. Francis, and K. Schipper, "Have financial statements lost their relevance?", Journal of Accounting Research, vol. 37, pp. 319-352, 1999.

[2] B. Lev, and P. Zarowin, "The boundaries of financial reporting and how to extend them", Journal of Accounting Research, vol. 37, pp. 353-385, 1999.

[3] G. Breton, and R.J. Taffler, "Accounting information and analyst stock recommendation decision: a content analysis approach”, Accounting and Business Research, vol. 31, pp. 91-101, 2001. 
[4] B. Lev, and J.H. Daum, "The dominance of intangible assets: consequences for enterprise management and corporate reporting", Measuring Business Excellence, vol. 8, pp. 6-17, 2004.

[5] S. Wallman, "The future of accounting and disclosure in an evolving world: the need for a dramatic change", Accounting Horizons, vol. 9, pp. 81-91, 1995.

[6] American Institute of Certified Public Accountants [AICPA], Improving business reporting - A customer focus. Meeting the information need of investors and creditors, comprehensive report of the special committee on financial reporting (the Jenkins report), New York, NY: American Institute of Certified Public Accountants, 1994.

[7] Accounting Standard Board [ASB], Reporting statement: operating and financial review, London, UK: Accounting Standard Board, 2006.

[8] Canadian Institute of Chartered Accountants [CICA], Management's discussion and analysis; guidance on preparation and disclosure, Toronto, Ontario: Canadian Institute of Chartered Accountants, 2009.

[9] Financial Accounting Standards Board [FASB], Improving business reporting: insights into enhancing voluntary disclosures, Steering Committee Report, Business Reporting Research Project, Norwalk, Connecticut: Financial Accounting Standards Board, 2001.

[10] International Accounting Standards Board [IASB], Management Commentary, IFRS Practice Statement, London, UK: International Accounting Standards Board, 2010.

[11] L. Edvinsson, "Developing intellectual capital at Skandia", Long Range Planning, vol. 30, pp. 366-373, 1997.

[12] K. Sveiby, The New Organizational Wealth, Managing \& Measuring Knowledge-based Assets, Berrett-Koehler Publishers Inc, San Francisco, CA, 1997.

[13] L. Edvinsson, "Some perspectives on intangibles and intellectual capital 2000", Journal of Intellectual Capital, vol. 1, pp. 12-16, 2000.

[14] J. Guthrie, and R. Petty, "Intellectual capital: Australian annual reporting practices", Journal of Intellectual Capital, vol. 1, pp. 241-251, 2000.

[15] G. White, A. Lee, and G. Tower, "Drivers of voluntary intellectual capital disclosure in listed biotechnology companies", Journal of Intellectual Capital, vol. 8, pp. 517-537, 2007.

[16] N. Brennan, "Reporting intellectual capital in annual reports: evidence from Ireland", Accounting, Auditing \& Accountability Journal, vol. 14, pp. 423-436, 2001.

[17] S.M. Williams, "Is intellectual capital performance and disclosure practices related?", Journal of Intellectual Capital, vol. 2, pp. 192-203, 2001.
[18] S. Bozzolan, P. O’Regan, and F. Ricceri, "Intellectual capital disclosure (ICD). A comparison of Italy and the UK", Journal of Human Resource Costing \& Accounting, vol. 10, pp. 92-113, 2006.

[19] S. Bozzolan, F. Favotto, and F. Ricceri, "Italian annual intellectual capital disclosure. An empirical analysis", Journal of Intellectual Capital, vol. 4, pp. 543-558, 2003.

[20] P.N. Bukh, C. Nielsen, P. Gormsen, and J. Mouritsen, "Disclosure of information on intellectual capital in Danish IPO prospectuses", Accounting, Auditing \& Accountability Journal, vol. 18, pp. 713-732, 2005.

[21] E. García-Meca, and I. Martínez, "Assessing the quality of disclosure on intangibles in the Spanish capital market", European Business Review, vol. 17, pp. 305-313, 2005.

[22] L. Oliveira, L.L. Rodrigues, and R. Craig, "Firm-specific determinants of intangibles reporting: evidence from the Portuguese stock market”, Journal of Human Resource Costing \& Accounting, vol. 10, pp. 11-33, 2006.

[23] I. Singh, and J-L.W.M. Van der Zahn, "Determinants of intellectual capital disclosure in prospectuses of initial public offerings", Accounting and Business Research, vol. 38, pp. 409-431, 2008.

[24] R.H. Whiting, and J.C. Miller, "Voluntary disclosure of intellectual capital in New Zealand annual reports and the "hidden value"', Journal of Human Resource Costing \& Accounting, vol. 12, pp. 26-50, 2008.

[25] F. Giunta, and M. Pisani, Il bilancio, Milano, IT: Apogeo, 2005.

[26] A. Quagli, Comunicare il futuro. L'informativa economico-finanziaria di tipo previsionale delle società quotate italiane, Milano, IT: FrancoAngeli, 2004.

[27] Consiglio Nazionale dei Dottori Commercialisti e degli Esperti Contabili [CNDCEC], "La relazione sulla gestione art. 2428 codice civile. Informativa sull'ambiente e sul personale", March, 2009.

[28] K. Krippendorf, Content Analysis: An Introduction to Its Methodology, Beverly Hills, CA : Sage publications, 1980.

[29] J. Guthrie, R. Petty, K. Yongvanich, and F. Ricceri, "Using content analysis as a research method to inquire into intellectual capital reporting", Journal of Intellectual Capital, vol. 5, pp. 282-293, 2004.

[30] V. Beattie, B. McInnes, and S. Fearnley, "A methodology for analyzing and evaluating narratives in annual reports: a comprehensive descriptive profile and metrics for disclosure quality attributes", Accounting Forum, vol. 28, pp. 205-236, 2004. 